\title{
Cosmological Orientation in Promoting the Enrollment in Short- Term Mobile Skill-Trainings: A Narrative Inquiry on Women's Lives in Nepal ${ }^{1}$
}

\author{
Devendra Adhikari \\ M. Phil in Development Studies, \\ Kathmandu University, School of Education, \\ Hattiban,Laltipur, Nepal \\ Email for correspondence: free.sky01@yahoo.com
}

\begin{abstract}
The Government of Nepal has prioritized the need of mobile skill-training program for imparting the skill-training opportunities to the potential beneficiaries in their own settlement both in urban and rural areas. It is different from the centrally based training program as it is conducted by setting temporary training venues in particular settlement where the training participants are residing in the majority. This paper describes how adult women exhibit readiness to participate in the shortterm mobile skill-training program in Nepal. The paper is based on a qualitative study with an interpretative paradigm following the narrative inquiry approach. The four participants were selected based on their experiences of receiving the training through mobile skill training program and currently employed in the trained trades. The interpretations of their life stories reveals that women in Nepal choose to enroll in the short-term mobile skill-training program as they believe it to be a gateway for them to get social recognition. Likewise, they prefer closer training venue and short duration training program due to their responsibilities towards their family. The findings of this research are useful in framing appropriate plans and policies for conducting short-term vocational training programs in mobile venues for bringing socio-economic changes in women's lives by respecting their family value system.
\end{abstract}

Keywords: Social recognition, Mobile skill-training, Soft skills, Local cosmology

\section{Technical Education in Nepal's Planned Development: Gender Perspectives}

There is a long history in the development of technical education and vocational training in Nepal. The first education commission report of Nepal in 1954, suggested that "technical and professional training institutions should be started at once" (The Nepal National Education Planning Commission, 1954, p.

1 This article is completely based on my M. Phil thesis entitled " Contribution of Short-term skills Training: A Narrative Inquiry on women's Lives "

submitted to Kathmandu University. 
64). During that period, scholarship were provided to students to motivate them to learn technical skills. It also emphasized on providing a uniform type of education system for both boys and girls. The report prepared at that period by the government agencies was an important milestone in modernizing the education system in Nepal and promoting girls' education.

The establishment of the Council of Technical Education and Vocational Training (CTEVT) in 1989 was an important milestone and an historical achievement in the vocational training sector of Nepal. It was formed as an autonomous institution to coordinate and facilitate the progress of the entire TVET sector of the country. Besides, its role is to assure the quality of TVET programs, grading the skill competency of an individual, capacity building of technical trainers, study and research, monitoring and evaluation and coordinating agency among the training service providers. Under this apex body, a large chain of 34 affiliated schools, 185 schools following TVET curriculum, 429 private TVET institutes, and 650 short-term training providing institutes have been formed (CTEVT, 2018). Similarly, the secondary level education has also started to incorporate the technical and vocational education (Ministry of Education [MoE], 2016 a). The declaration of providing free education up to the secondary level to every citizen by the constitution of Nepal (2015) has even enlarged hope in the capacity development activities among the socially and culturally discriminated groups including women.

CTEVT is imparting technical education and vocational training in the form of diploma, technical school leaving certificate, special technical education and short-term technical education course. The shortterm training is most preferred by the youths as they become skillful in a short span of time. The training service providers can conduct the short-term mobile skill training as a central training program, mobileskill-training program, and apprenticeship-training program (CTEVT, 2017a). In central training program, the training venues are confined in city areas or in already established infrastructural setup venues of training service providers. Likewise, apprenticeship training is industry-based training, where the participants learn the skill in the real workplace. Alternatively, the mobile skill-training program is the decentralized form of the training program, where the training programs are conducted at particular settlements where most of the training participants are residing.

The skill impartment has generated a large number of skilled human resources in the country. Nevertheless, the recent data of the government shows that out of 922,445 industrial establishments in Nepal, the total 3,408,746 people are employed, in which 2,044,989 are males and 1,363,757 are females. The sex ratio of employment status is 150 (CBS, 2018). This indicates that women have less contribution to the productive sector in comparison to their male counterparts in Nepal. This could be the reason the Government of Nepal has been providing vocational skill development activities to both male and female from the fiscal year 2005/06 to $2016 / 17$ (till first 8 months), in which $1,03,873$ females and 95,295 males have received the vocational skills training in different trades till now (Ministry of Finance [MoF], 2017). The capacity building opportunity given to a large number of females in this period through vocational training activities is a concrete step taken by the Government of Nepal to reduce economic disparity in gender by promoting their involvement in productive income generating sectors through their skill development. In other words, the country's policies, donors' progressive steps, and civil society movements have really feminized the vocational training sector in Nepal.

\section{Mobile Skill-training Program: Changing Lives at Micro Level}

Mobile skill-training program is conducted at the settlement level by conducting training need assessment or rapid market appraisal there. The temporary training venues are set by hiring rooms at community schools, buildings, or making a 
temporary hall in an open space. The training is conducted with all necessary inputs like trainers, tools, equipment, daily consumables, and safety measures. The main intention of this training program is to provide training opportunities to the deserving participants at their own place. Thus the skill transfer through the mobile skill-training program has become an important means of human development in our rural villages as well as in the urban settlements, where people cannot travel long distance daily to take part in the training program.

The neo-liberal concept of expansion of skill development activities in Nepal is also expected to have linked with the regular growth in productivity. It is argued that "the neoliberal state should favor strong individual private property rights, the rule of law, and the institutions of freely functioning market and free trade" (Harvey, 2005, p. 64). Nonetheless, the various claims of development partners and the Government of Nepal are quite pessimistic towards the contributing role of the vocational training sector in the macroeconomic perspectives in Nepal. A report of Asian Development Bank has identified the key issues which have deflated the TVET sector as " insufficient and inequitable access, poor quality, low market relevancy, and weak and outdated institutional capacity"'(ADB, 2013, p. 2). Even, government data shows the generation of skilled labor and the creation of employment opportunities have not been achieved till date. Government data from the Ministry of Finance (MoF) shows the generation of the skilled workforce and the creation of employment opportunities have not been achieved as needed in Nepal. There are still thousands of youths leaving Nepal every day out of which only $1.5 \%$ of them are skilled, $24 \%$ are semi-skilled and $74 \%$ are unskilled. Altogether 500 thousand youths are estimated to enter in the labor market every year but only below 25,000 youths are recorded to be trained through vocational skill annually (MoF, 2018). If the generation of the skilled human resource is low, the productive contribution from them in the economic growth to the macro-economy cannot be envisaged. Similarly, a report of the Central Bureau of Statistics claims that women are more engaged in the non-productive sector than their male counterpart in Nepal (CBS, 2018).

Instead of these facts, I have witnessed that a large number of women still attracted to short-term mobile skill-training program for empowering and changing their lives socially and economically. Garbuja and Pasa (2016) have also highlighted that the skilled and employed women are playing a vital role in the society in making community decision, leading different sectors that affect their living and acting as a change agent in the society. However, the literature is silent on the types of training program that women want to get enrolled. In this discourse, though there are many policy discussions and donors' concern regarding the skill development sector in Nepal, a study on the narrative voices of the trained female graduates of the mobile skill-training program about their preference for choosing and enrolling in the mobile skill-training program is still missing. Thus the purpose of this paper is to explore the reasons behind exhibiting the readiness of women to get enrolled in a short-term mobile skill-training program by bringing the narrations of their life experiences. Research Methodology: Narrative Inquiry Hearing stories about the life experiences of the research participants and observations of the enterprise opened by them were the methods of information collections, which I used to explore the multiple realities of the lives of my participants. With these, I came across the hurdles that obstruct the conversion of the learned skills into enterprises by women.

For the research site, I chose a heterogeneous settlement in ward no. 14 of Lalitpur Metropolitan city as many women there had already received the skill-training program through the mobile skilltraining program and they have changed their living by establishing enterprises or doing the job in the trained trade. In this paper, I gathered the stories of my four graduates from two different training trades: assistant beautician and tailoring. My research participants are Gamala Chhetri (29), Bharati Chhetri 
(27) Safali Tamang (30) and Sulochana Brahmin (40). Gamala , a newly married daughter in law, received a three months assistant beautician training from the venue, funded by the donor at the venue just half an hour far from her home. She has opened a parlor cum cosmetics shop. Sulochana, a victim of gender-based violence, received the same training along with Gamala. Similarly, Bharati received the assistant beautician training at a private training institute nearby city center. Likewise, Safali received the tailoring training through the mobile skill-training program and opened a tailor at her own home. These participants have been selected on the assurance that they have sufficient knowledge and experience and express their readiness to get enrolled in the mobile skill-training program.

In this regard, I chose narrative inquiry to inquire as I was studying the lives of individuals and asking them to provide stories of their life (Willis, 2007). I chose the literature of Clandinin and Huber (2010), where the stories of the participants are gathered in the periphery of time, place and society and the meaning making is made throughout these dimensions. For the information gathering, I visited the enterprises of the participant for at least three times until I got the required information. I interacted with them using Nepali Language and the same narrations have been used as the field-text of this research. I used persistent observation of their enterprising activities and conducted in-depth interviews for gathering the information. I was engaged in the field for more than six months and even conducted the peer debriefing with my University professors, research supervisors and colleagues. This helped me to get different insights by understanding the stories of the lives of my participants. Regarding the ethical consideration, I did not cause any harm to my participants, have maintained confidentiality of their identity and seriously undertaken the gender issues. The meanings have been aligned with the research question and are informed by the theory of social recognition.

\section{Theorizing the Discussion}

In our society, most of the women are enrolled in the training programs for changing their prevailing condition due to the exclusion caused by social and economic structure here. Kompridis (2007) focuses that an individual suffering from the injustices like social, political and cultural discriminations, which hinders him/her from realizing self, cannot become what he/she wants to be in the future and cannot shape their destiny. This is the deadliest form of injustice that an individual suffers in his/her life. This pushes the individuals to introduce themselves as enabling the persons of the society by integrating themselves in this social setting. As soon as they get the freedom to govern self after getting a kind of identity in society, they materialize their dream into reality, which leads to their social recognition. With the use of the above-mentioned theory, I have interpreted the stories of the lives of my participants by generating the following themes. The narrations of the participants have exposed that enrolling in the training program was the turning point in their lives enabling them to achieve the status of being recognizable in society.

\section{Facing Discrimination: Because I am a Girl}

Most of the women in our society, who have chosen to acquire the vocational skills in their lives in their adulthood, have desired a change in their lives. Willingness for the change means their earlier living was not comfortable. Some of them have even witnessed different types of injustice during their childhood days, which was misrecognition to their presence in this society.

Gamala revealed that she is only tenth grade passed. Her mother, father, and single brother at maiti ${ }^{2}$ are also not much educated. Until the primary grades, her parents admitted her at a local government school and then she was later transferred to a private school. She was very weak in English. She hardly passed the SLC exam and joined grade eleven in a government campus. However, she could not complete all her papers and failed in English even

2 A birth home of a girl before marriage 
in the second attempt. She was already twenty-one years old. Her family then started searching for a good family for her marriage and finally, she got married. She said:

I had a desire to study up to Bachelor level and work as a teacher. However, I stopped in grade eleven. Neither did I succeeded in passing, nor did my family members motivated me to focus on my studies. Therefore, I dropped my education there. Then my parents arranged for my marriage. After the marriage, I was afraid to talk with other people, going to the market, visiting the relatives and neighbors thinking that I am different and immensely behind the other people in good qualities So, I enjoyed working inside my house and taking care of the sick mother-in-law.

Listening to Gamala's story, I was surprised to learn that even the family members of college going girls plan for their marriage if they could not pass their exams. The girls in our society do not even have any options than to go along with the choices of their parents who make the decision for them which shapes their lives. Psychologically, they become enslaved with the family decision. This was a kind of unjustifiable situation in their lives.

Upon discussion with another participant Sulochana, I found that she was a victim of child marriage and had even faced severe gender violence from her husband. Upon probing, she revealed that she was married at the age of thirteen. By then, she had just completed grade three. She was the eldest among five siblings (four daughters and one son). For the desire of a son, her parents had had four daughters before finally getting a son. As per the culture, a son is desired by every family. Poudel (2018) has also mentioned that in Nepal if there is son on the first delivery, then the parents do not wish to have another child. In contrast, if there is a daughter as the first child, most of the parents do identification of the fetus during the pregnancy period and go for an abortion if there is again a daughter. This is a bitter reality of our society.

Due to this deep-rooted social practice, parents are in a hurry to find a husband for their daughter thinking that they will become free from their parental responsibilities and can better take care of their son. Sulochana faced the same thing in her life, she could not oppose her parents as she was not mature at that time. Therefore, she happily tied a nuptial knot with the person who was seven years older than her. But her parents' good wishes towards her life did not take place. She further said:

After marriage, my husband and I were living together happily and I gave birth to two children. As time passed, I do not know why my husband's behavior started to change. He started having an extramarital relationship with another woman. He started scolding and beating me. Later on, he married that woman and started living separately.

The above-mentioned disheartening story of Sulochana reveals her sufferings due to child marriage and the exploitation she suffered from her husband. Just for being a female, she faced extreme genderbased violence in the name of early marriage or polygamy.

\section{A Girl's Family: Equally Responsible for Her Good Future}

Examining the narrations of the participants from different angles, I have further revealed that the perception of the family members towards their daughters is always not patriarchal in our society. When the girls are grown, it is a common societal rule that father or elder brother seeks good bridegroom for them. The social structure is constructed as such. I continued to do probing whether the parental structures in the eastern societies always follow the discriminatory practices towards the girls or there are some other meanings. For Gamala, though her parents were not serious about her studies, they were very much alert that her future husband should be from a good family 
background having at least a house in Kathmandu. They searched and talked with different families through the network of relatives and finally, they agreed with the person who was qualified, employed and had a house in Kathmandu. Gamala was chosen as the bride of that family primarily to take care of her husband, sick mother-in-law and for doing kitchen work. At her maiti, she was instructed as it was the duty of the husband to earn money and her role was to manage the household affairs. With those teachings of her maiti, she became ready to tie the nuptial knot with the person at the settlement (research area). She said:

Though my first wish was to complete my college degree before marriage. At the same time, I could not object to my parents' wish for my good future after marrying a well-educated person. But I do not have any regret for doing so. I entered this house as a "ghar-garne ${ }^{3}$ " buhari ${ }^{4}$.

This narration of Gamala shows the support of the family members towards her good and secured future. A ghar-garne buhari has the major responsibility to look after the household works only. She has to take care of sick mother-in-law and husband. As her educational attainment was also very less, it would be very difficult for her to find official jobs. This was the reason her father and mother agreed about her marriage in that family. Marrying at the age of twenty-one was the right age for Gamala, and it should not be viewed from the perspective that they arranged for her marriage just to get rid of their parental responsibilities.

Sulochana always had some dissatisfaction with her maiti's mother and father. Hoping to give birth to a son, her mother had already given birth to four daughters before finally bearing a son. She agreed that due to large number of children made her parents poorer. She said:

It was very difficult for my father to buy school dresses, stationeries for four daughters and a son at a time. He used to work very hard, but we always had hands to mouth problem. Even they had no other options for feeding and caring such a large family. They dreamed that my husband and his family would take good care of me. So, that might be the reason, he arranged for my marriage, when I was just thirteen

I was surprised to know the bitter reality of our society. The impact of a big family has serious consequences with the education, hygiene, and nutrition of the children. Early marriage of the daughter is not the construct of our society, and rather the poverty plays a vital role in it. Further discussion with her reveled that her maiti continued to support her even after her marriage. When her husband started to torture her and started extramarital relation with another woman, the first thing she did was go to her maiti for help. She revealed all the incidents and behavior with her mother. Then immediately, her father and uncle went to meet her husband to settle the matter through family negotiation. The narrations of Sulochana revealed that the love and care of the maiti's father and mother did not stop even after her husband abandoned her. So, they regularly motivated their daughter to fight for getting justice, not losing hope and taking care of the children. Eventhough their economic condition was not good; their moral support always helped her to face any trouble coming in her life. Therefore, she neither divorced her husband who betrayed her nor leave the husband's home and children. Later on, her husband himself stopped coming to there. The support of the family members of her maiti plays a crucial role in this situation.

Safali had a bitter childhood experience. She came to Kathmandu to work as a domestic child labor at a rich person's home. Her father had accompanied her during her first journey. I was a little bit upset upon hearing her sad stories. Some questions that arose in my mind were: How could any father and mother be so cruel to send to their small daughter

3 To look after the household works only

4 Daughter-in-law 
of just age twelve to an unknown hand? With this, I continued to probe her flashback stories of her to dig out why her parents were compelled to send her to work as domestic child labor. She continued saying:

No sir, my father is a very good person and so is my mother. My house is in the remote village of Rasuwa district. We were very poor. My parents did not have other sources of income, except agriculture. Meanwhile, my father had knowing relation with one rich Rana family in Kathmandu. He talked with them and brought me to Kathmandu from the village to work as a labor in their house. He made a verbal agreement with them that they should provide the monthly salary as well as admit me at a government school. Instead, the Rana family just provided me with the said money, but they did not enroll me at schools. On yearly visits, my father frequently requested them to fulfill their promise. Nevertheless, no one in the host family considered my father's request.

Listening to the heart touching story of Safali and other participants, I made an interpretation that the reality what we believe existed is subjective. It is the poverty, which compels the innocent parents to send their small daughters to work at other people's home, arrange for their early marriage and so on. The parents have an equally serious concern and care towards their children, boy or girl. In the case of Safali too, her father handed her over to a knownhost family hoping that she might get good care and education. He himself came to drop her and made an annual visit. Thus the love and care of parents do not cease even if the daughters are not in their sight. This is our social construct.

\section{A Girl in the Midst of Injustice and Care: Dream of Change Bubbling}

The unjustifiable situations in the forefront and the supportive behavior in the backstage by the family structure in the lives of most of the women provoked them to get some identity inside their home and in the broader society. As they gradually became mature, they started envisioning of enrolling in the vocational training program, opening self-enterprises or engaging in the related jobs and changing their lives. This stage appeared gradually as their maturity and awareness level developed.

While listening to the life stories of Gamala, she continued that as the time elapsed, her child began to go to school. There was also pressure from the family members, community people and her parents at maiti to engage in some earning work, as there was little to do at home. Her parents also told her that if she could earn something herself, it would definitely contribute to the household expenses. In addition, in her surroundings, she saw other women going to work and earn money. This motivated her to get enrolled in the training. She said: In this place (study area), there are many young married women who are employed as a teacher, banker, as money collector in cooperatives, as a receptionist in colleges, as a nurse in hospitals and so on, as they are qualified. Therefore, I felt that I should engage myself in some works, otherwise the people in the community would dominate me. I even started thinking that people in society would compare my educational status with my husband's and start their useless gossiping. Some wild ideas came in mind that I should change my status from unemployed and unqualified women. So, I chose to be self-employed and for it, learning a skill and opening some kind of enterprise at my home was the only option for me as my academic qualification was very less. And I also had to look after my sick mother-in-law, small child and do the daily household activities. So, I wished to join the skill-training.

Hearing the conversation of Gamala, I made meaning that these extrinsic motivations of the family members and the internal realization triggered them into 
experimenting with some new things to change the existing distressful situation. Besides, if the social structure of the new community views that the women's engagement in professional work is a good practice so that they can share the economic burden of the family members, and it will also inspire them to become self-dependent. For the first time, I realized that triangular connections between the family support, community people's encouragement, and self-dream drove these women towards the skilltraining program.

\section{Governing Self and Enrolling in the $\mathrm{MST}^{5}$ : By Balancing the Family Structure}

After cherishing the dream, adult women wait for some favorable conditions in their lives, which allow them to live their lives as per their dream. This is the transformational stage in their lives for governing self with the personal decision of being admitted into the skill-training activities. This phase appeared in most of their lives after their marriage or developing adulthood in them. Having developed courage towards changing their prevailing livelihood helped them towards living life as per their wish. They started to think and act accordingly by hearing their own inner voice to build their brighter career at this stage.

Gamala's life passed normally until she became a mother and her child started to go to school. After she gave birth to a son, the situation at her home became good. Her husband used to go to the office and her previously sick mother-in-law gradually became healthy. Then she wanted to change her living conditions by receiving some vocational training. However, being a buhari ${ }^{6}$ of a family and mother of a small child, it was not possible for her to participate in training programs which was conducted at venues far from home. For this reason, she waited until she knew about the training program, which was going to be conducted within walking distance from her home.
Luckily, she got the information about the training, which wa to be conducted at Hattiban, Lalitpur which was only thirty-five minutes walk from her house. In addition, the training was free of cost financed by the Enhanced Vocational Education and Training project under the Ministry of Education and the schedule was only for short period, i.e. 390 hours (three months). The training service provider was a private training service provider, headquartered in Butwal, western Nepal, and the Hattiban training venue was a mobile skill-training venue. In this regard, Gamala articulated:

I consulted my husband about my interest
in receiving the training and he agreed on
it saying that I should not compromise to
give daily medicines to my mother in law.
Then I got enrolled in the training by filling
the form during the skill fair at Brihikuti
Mandap. I was very much excited to know
that the training was going to be conducted
around Satdobato area, which would be
very close to my house. In addition, it was
free of cost, with a free lunch of Rs. 50
daily. Moreover, after passing the training
we would get the certificate of CTEVT,
Level-1. I would never achieve this if the
training program was conducted at other
areas far from my home.

From her experience, it can be said that adult women are always ready to learn new things. Though there are social and cultural restrictions for women to learn the vocational skills, they mostly prefer the training venues that are close to their house and choose the training program that makes them skillful in a short period. Besides, the training was government funded, free of cost, conducted as per the standard of CTEVT, provision of free lunch during the training and provision of free exam of National Skill Testing Board was enough motivating for women to get enrolled in the training program. Thus, freedom from household works and parental restrictions played a vital role in encouraging her to 
get enrolled in the skill-training program. This helped her to get closer to her dream to get a recognizable status in society by being skilled and then employed.

The case of Bharati was different, after completing the School Leaving Certificate exam, there is three months break from school in Nepal. Her friends joined basic computer courses and bridge courses to get enrolled in college and language classes to develop different skills. With lots of dilemma in mind, she listened to the inner core of her heart and she got enrolled in the beautician training class. By making a grim face, she said:

It was my hobby to do the work of beautician and it dragged me to get that training. So, I got enrolled in beautician training. Learning the English language and computer course were not matters of my interest.

She searched for many training institutes for the training. Among them, she got enrolled in ITC training center at Lagankhel as she heard that ITC was a good network of beauty parlor training institutes. Though it's main operating office was at Kathmandu, its branch offices were in the major city areas of the country. She got enrolled at the Lagankhel branch as it was not very far from her living place, which could be feasible for her daily up down. Bharati's stories disclose that for a hard working person, the education barrier does not restrict to live their lives as per their interest and plans. The discrimination faced by women from an early age probably nurtures low esteem in them. Instead, if they choose to learn and utilize the vocational skill to bring positive changes in their lives, it will develop their inner strength and help them set their future goals of survival as per their inner wish. The gradual growth in their adulthood drives them to live their life independently in achieving their desired aim.

\section{Mobile Skill-Training Program: Gateway towards Social Recognition}

The participants' stories have revealed that they participated in the vocational training program to make themselves recognizable in the broader society, apart from getting economic empowerment. Fluck (2012) has also stated that misrecognition has become a great threat to the democratic norms and values of today's society. If people are misrecognized in the name of gender, discrimination or exclusion from the societal rules, then it is an extreme form of social injustice. Thus if the social-cultural identities and values of the voiceless group of the society are not wholly recognized, then there is a damaging effect on their identities. The initial narrations of the participants also signify that they were discriminated just for being a woman. This provoked them to get a respected identity in society in their adult life. Barbosa and Dujo (2015) mentioned that the social conflict in the periphery of recognition can be addressed by quality education. Education can be a mediating tool for helping the voiceless people in building their empowerment for fighting against exclusion and getting their rights. Thus the learning through non-formal education, i.e. imparting the vocational skills through the mobile skill-training program has enlarged the wishes of most of the females being recognized in the prevailing social structure of Nepal.

It is necessary that every individual in the society gets equal respect and value. Heidegren (2004) has explained recognition as the process of integrating the members in a society. Likewise, viewing from the micro level, it is related to the "socialization and the identity" of an individual (Heidren, 2004, p.365). The female participants of this research are also in search of getting ways to introduce themselves as an important members of the society. Their socialization process was very weak and they faced different levels of gender-based violence during their childhood and adulthood period, which caused them to live life in a suppressive way.

Kompridis (2007) has described recognition as selfrecognition and social recognition. In the literature, we can find three constructs of social recognition: injustice, identity, and freedom. The writings argue that not just injustice and identity-less make an 
individual misrecognized but it is an "unjustifiable curtailment of our freedom to govern ourselves" ( $p$. 287). The long years of suppression faced by voiceless group in the society put them in the stage of injustice and being identity-less. However, during their adulthood, they started to see the right and wrong in society and what has been happening to them. This motivated them to seek broader freedom in their lives. Thus recognition is the matter of injustice and identity in the primitive stage and it is a matter of getting freedom in the latter stage. The stage of transformation from injustice to getting identity and identity to freedom makes an individual recognized in the larger society.

Besides, in this research, along with the niches of recognition theory: injustice, identity, and freedom, the participant stories have revealed some other important claims, which are contextual and relevant to our social socio-cultural structure. Whenever they had freedom from their parental responsibilities and they would have an influential role in their houses in decision-making level, they chose to learn vocational training through the skill-training program as a means for being recognized in the society and to get economic empowerment. In line with this, they have chosen the training program, which is conducted for a short period and the training venues, which are close to their home. This is because they have different parental and socio-cultural responsibilities, being buharis of the family. In this way, they become ready to learn through short-term mobile skill-training program as a gateway for entering towards a better life.

There is no doubt that the discrimination towards the female is rampant. The only thing that can minimize this is by imparting value education as it gradually develops good human characters (Chaudhari, 2016). However, this is only a partial truth as claimed by Kompridis (2007) that the excluded groups suffer from the injustice that is hindering them to integrate into society. Besides, in eastern societies, there are promoting factors like the culture of love, care and respects towards the girls in our society. It is the poverty, which forces the parents to marry off their daughter at an early age, providing them with poor education, or forcing the girls to work as child labor at others' home. The parents are always worried about the good future of their daughters after marriage whether or not they will get a noble husband and caring in-laws. It is the parents of the maiti, who stand behind the married women if they get any trauma and sufferings in their post-marriage life. Additionally, the females, whenever get the freedom of governing self, they do not go against the family traditions by disrespecting the seniors of the family, without taking their consent to participate in the training or without performing their assigned duty. In this research, after the females get the freedom to get enrolled in the training program, they choose the training venue that is very close to their house and the training program being conducted for a short span of time. This helped them as they could manage time to look after their small children, prepare food for all family members, take care of old and sick in-laws, take care of their farm and livestock. In this way, they get a chance to develop their capacity through the skilltraining and easily manage their family affairs as well.

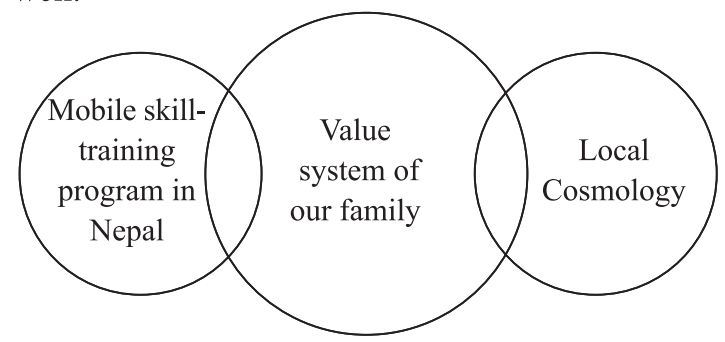

Figure 1: Chart showing the intersection between Mobile skill-training program and local cosmology in Nepal

Choosing a closer training venue for enrollment and capacity building is guided by the family's value system of our eastern societies. Awasthi and Yamphu (2017) have pointed out that the local cosmology is speculative insights that help to interpret the constructed truth in a particular context since generation. The practice, rules, and ways of the living 
are not the byproducts of a couple of years. It takes thousands of years to generate a pearl of wisdom, which guides the society. Our eastern local cosmology helps to give shape to the family system, cultural rituals, festivals, and beliefs. These have become our approach to existence from generations. Of course, all of the research participants here are not from the Hindu community though they have been influenced by the Hindu way of life because for a long period in our history, Nepal remained a Hindu dominant state and this religion holds some "state power and policy attached to it" (Awasthi, 2004, p. 89).

\section{Winding Up and Implications}

The participants in this research were in the dire need of some vocational training programs that could bring some renovations in their lives. In the midst of so-called discrimination and care, they dream of change bubbles in their lives. When they got enough freedom to govern self, they chose the pathway of learning skills through the short-term mobile skilltraining program. For this also, they did not revolt against the family system but convinced all the family members about their plan to change themselves and support the family's burden by developing their capacity through the skill development program. They got enrolled in the training program with the family's effort as well. In order to perform the regular household works, take care of small children and old family member as well as sick in-laws, look after the family farm and livestock, they chose the training venue close to their home with short duration, which is jargoned as a short-term mobile skill-training program. This signifies that they wanted to get recognition in the society after learning the skills by respecting the value system of the family. Besides, initiating different poverty minimization campaigns and incorporation of value education based on eastern philosophies in our academic curriculum can gradually reduce the discriminatory practices against women in our society. Thus policymakers and practitioners should promote the short-term mobile skill-training program in Nepal as it very suitable for women, where they can get easy enrollment and support of their family.

\section{References}

Asian Development Bank. (2013). Nepal: Supporting Education and Skills Development. Kathmandu. : Author.

Awasthi, L. D. (2004). Exploring the monolingual school practices in multilingual Nepal (Unpublished doctoral dissertation). Danish University of Education, Copenhagen, Denmark.

Awasthi, L. D. \& Yamphu, I. M. (2017). Diversity in education [Lecture note]. Kathmandu University. M Phil in Education.

Barbosa, M.G., \& Dujo, A.G. (2015). Education and struggles for recognition: the strategic role of empowerment. Revista Española de Pedagogía, Vol. 74, No. 264 (mayo-agosto 2016), pp. 283 296. Universidad Internacional de La Rioja (UNIR). Retrieved from: https://www.jstor.org/ stable/24711385

Central Bureau of Statistics. (2018). Preliminary results of national economic Census 2018 of Nepal. Kathmandu: Author.

Chaudhari, M. V. (2016). Education system and Sanskrit language of Vedic age. Research Guru. Volume-10 Issue-3(December,2016) (ISSN:2349 266X) . Retrieved from: http://www.researchguru. net/volume/Volume\% 2010/Issue\%203/ RG10MV3-2.pdf on 7 December, 2018

Clandinin, D.J., \& Huber, J. (2010). Narrative inquiry. In B. McGaw, E. \& P. P. Peterson (Eds.), International encyclopedia of education ( $3^{\text {rd }}$ ed.). New York, NY: Elsevier.

Council for Technical Education and Vocational Training (2017a). About us. Retrieved from http://ctevt.org.np/page.php?page $=1$ on February 17,2018

Council for Technical Education and Vocational Training. (2018). Annual report 2073/74. 
Kathmandu: Author.

Fluck, W. (2012). Fiction and the Struggle for Recognition. Universitätsverlag winter Gmbh. Retrieved from: https://www.jstor.org/ stable/43485846

Garbuja, B. P ., \& Pasa, R. B. (2016). Role of technical and vocational education and training in women empowerment: A case from Bhima VDC of Myagdi district, Nepal. Journal of training and development. TITI: Kathmandu.

Harvey, D. (2005). The neoliberal state. A brief history of neoliberalism. New York: Oxford university press.

Heidegren, C. (2004). Recognition and social theory. Acta sociologica. Los Angles: Sage publications. Retrieved from: https://www.jstor.org/stable/ 4195050 on 31-July-2018

Kompridis, N. (2007). Struggling over the Meaning of Recognition A Matter of Identity, Justice, or Freedom? European journal of political theory. Los Angles: Sage publications.

Ministry of Education. (2016 a). School sector development plan. Kathmandu: Author.

Ministry of Finance. (2018). Economic Survey: 2017/18. Kathmandu: Author.

Poudel. A. (2018, August 13).Chorilai janmanai nisedh [Daughters are restricted to born]. Nayapatrika national daily publication, p. 1

The Constitution of Nepal. (2015).

The Nepal National Education Planning Commission. (1954). Education in Nepal. Kathmandu: The Bureau of publications and college of education.

Willis, J.W. (2007). History and foundations of interpretivist research. Foundation of qualitative research. USA: Sage publications. 